\title{
Identifying Subgroups of Patients With Chronic Nonspecific Low Back Pain Based on a Multifactorial Approach: Protocol For a Prospective Study
}

Kevin Rose-Dulcina ${ }^{1,2,3}$, MSc; Nicolas Vuillerme ${ }^{2,3,4}, \mathrm{PhD}$; Anne Tabard-Fougère ${ }^{1,2,3}$, MSc; Romain Dayer ${ }^{5}$, MD; Dennis E Dominguez ${ }^{6}, \mathrm{MD}$; Stephane Armand ${ }^{1,3}, \mathrm{PhD}$; Stéphane Genevay ${ }^{7}$, MD

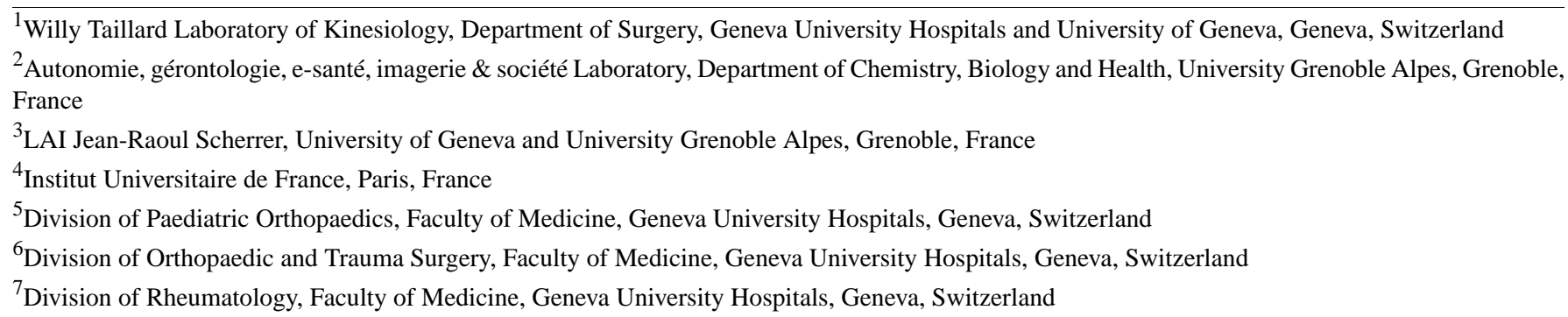

\section{Corresponding Author:}

Kevin Rose-Dulcina, MSc

Willy Taillard Laboratory of Kinesiology

Department of Surgery

Geneva University Hospitals and University of Geneva

1st Floor

Rue Gabrielle-Perret-Gentil 4

Geneva, 1205

Switzerland

Phone: 410223729164

Email: kevin.rose-dulcina@hcuge.ch

\begin{abstract}
Background: Low back pain, especially nonspecific chronic low back pain (LBP), the leading cause of disability worldwide, represents both social and economic problems. Different therapeutic management techniques can be used, but their effects vary. Clinicians and researchers attribute the variation in the efficacy of therapeutic and management techniques to the heterogeneity of the nonspecific chronic low back pain population, and they agree that nonspecific chronic LBP must be subgrouped.

Objective: This study aims to identify nonspecific chronic LBP subgroups based on a multifactorial approach, including biomechanical, physical, and psychosocial data.

Methods: A total of 100 nonspecific chronic LBP patients and 30 healthy participants aged between 18 and 60 years will be recruited for this prospective study. A psychosocial profile will be established using questionnaires on anxiety, depression, functional disability, pain, fear of pain, avoidance belief, and physical activity. A physical capacity evaluation will be conducted. It will evaluate flexibility of the hips, lumbar spine, and lateral thoracolumbar segment, as well as trunk (extensor and flexor) muscle endurance. The subjects will perform functional daily life activities, such as walking, object lifting, forward bending, sit-to-stand, stand-to-sit, balance, and usual postures. Full body kinematics, kinetics, and surface electromyography of the trunk and hip muscles will be assessed during these tasks. The clustering classification methods for the statistical analysis will be determined according to the data and will be used to identify the subgroups of nonspecific chronic LBP patients.

Results: Data collection started in September 2017 and will be completed with the inclusion of all the participants (100 nonspecific chronic LBP and 30 control). The study results will be published in peer-reviewed journals and presented at relevant international conferences.

Conclusions: Numerous studies have showed that the therapeutic management of nonspecific chronic LBP is difficult and has inconstant effects caused by the complexity and heterogeneity of nonspecific chronic LBP. Identifying subgroups with a multifactorial approach is more comprehensive and closer to the pathophysiology of nonspecific chronic LBP. It also represents
\end{abstract}


benefit interests and a challenge both clinically and socially. The perspective of this study is expected to support clinicians for a more adapted therapeutic management for each subgroup.

(JMIR Res Protoc 2018;7(4):e104) doi: 10.2196/resprot.9224

\section{KEYWORDS}

low back pain; chronic pain; activities of daily living; psychology; electromyography; biomechanical phenomena; classification

\section{Introduction}

\section{Background}

Low back pain (LBP) has been the leading cause of disability worldwide since 1990 [1] and has a lifetime prevalence of $84 \%$ in industrialized countries [2]. LBP is defined as pain and discomfort of varying duration. It is localized below the costal margin and above the inferior gluteal folds, with or without irradiation in the lower limb [3]. LBP is considered chronic when pain duration exceeds 3 months $[4,5]$ and accounts for $10 \%$ of the cases and represents $70 \%$ to $90 \%$ of the total LBP cost [6]. A recent study reported that chronic LBP treatment in the United States costs between US \$85 and US \$238 billion annually [7]. In Switzerland, chronic LBP costs between 1.6 and 2.3 of the gross domestic product [8]. In France, chronic LBP is one of the costliest diseases with 6-month direct costs of US $\$ 884,85$ per patient [9]. Furthermore, the World Health Organization recently reported that chronic LBP is one of the major causes of professional health-related absences [10]. Therefore, chronic LBP represents a significant worldwide problem with major medical, social, and economic impact.

Knowledge on the LBP pathophysiology is not sufficient. A precise diagnosis can only be obtained in $10 \%-15 \%$ of the cases $[11,12]$. Therefore, LBP is mostly categorized as nonspecific. Nonspecific LBP is a constellation of symptoms not attributable to a known specific pathology (ie, infection, tumor, osteoporosis, fracture, structural deformity, inflammatory disorder [eg, ankylosing spondylitis], radicular syndrome, and cauda equina syndrome) $[2,11,13,14]$. In addition, pathologies that are known as possible causes of pain (eg, osteoarthritis, disc disease, or cracked discs) do not explain the onset of symptoms on their own due to a similar prevalence of these pathologies being found in asymptomatic subjects $[2,15]$.

Nonspecific chronic LBP results from a variety of factors which can interact with each other. These include biomechanical, psychosocial, physical, environmental, genetic, and cultural factors [2]. The diversity of these factors and the complexity of their interactions could explain the difficulty in establishing a specific etiology of nonspecific chronic LBP. In the absence of a clear diagnosis, physicians face a therapeutic challenge caused by the large number of available treatments (eg, drugs, physiotherapy, physical exercise), for which the overall effect is small to moderate [16]. The poor efficiency of the available treatments is attributed to the heterogeneity of nonspecific chronic LBP patients [17]. Therefore, identifying nonspecific chronic LBP patient subgroups is essential [18] and will help optimize therapeutic management [19-22]. The need for nonspecific chronic LBP patient subgroups was highlighted by $84 \%$ of primary care clinicians on a large-scale survey [18].

\section{Prior Work}

Numerous differences between nonspecific chronic LBP patients and healthy subjects were reported using various clinical features. Regarding genetic factors, some studies have reported that genes result in a predisposition to intervertebral disc degeneration [23] or can alter pain perception [24]. Psychological factors, such as pain catastrophyzing, are altered in nonspecific chronic LBP patients and can influence physical performance [25]. In terms of physical capacities, the nonspecific chronic LBP population presented with reduced endurance and higher fatigability of the trunk extensor muscles [26] and lower hip and lumbar flexibility, correlating with nonspecific chronic LBP severity [27]. With regards to biomechanical factors, nonspecific chronic LBP patients exhibited kinematic and muscle activity impairments [28,29]. When compared to healthy subjects, nonspecific chronic LBP patients showed decreased pelvis rotation during gait [29] and an increased stiffness of the spino-pelvic complex [30]. Moreover, nonspecific chronic LBP patients presented with decreased maximum range of motion and velocity between the lumbar spine and the hips during the sit-to-stand (STS) task [31] associated with stiffer spine movements [32]. Meanwhile, during the lifting task, they used different kinematic strategies, especially in lift speed and hip and knee flexion [33] and presented with less variability in kinematic patterns [34]. Alterations were also found in the trunk and hip muscle surface electromyography (sEMG). Nonspecific chronic LBP subjects presented with higher global trunk muscle activity during gait [35] or lifting tasks [36]. Many studies highlighted an exacerbated lumbar erector spinae activity (absence of the flexion-relaxation phenomenon) at full trunk forward flexion [37-39].

Nonspecific chronic LBP patient subgroups have previously been identified based on biomechanical parameters. Slaboda et al [40] identified 2 subgroups based on lift kinematic patterns, whereas Dankearts et al [20] discriminated 2 subgroups based on sitting posture. They also discriminated the subgroups on trunk muscle activity, posture, and movement [20,41], which make the biomechanical analysis of nonspecific chronic LBP patients relevant for a better understanding of this pathology and could help to discriminate different subgroups.

However, identifying subgroups only from a biomechanical analysis is not comprehensive enough due to the emotional and behavioral consequences of pain, which contributes to the persistence of pain and treatment outcomes, and due to the multi-factorial features of nonspecific chronic LBP [42]. Anxiety and depression play a major role in pain chronicity in nonspecific chronic LBP patients [43]. Psychosocial parameters have also been observed to influence kinematic and muscle activities. Indeed, a high level of pain catastrophizing was 
associated with a decrease in the activation time of the spinal muscle (multifidus) in LBP patients during forward bending [44] and a lower performance time in the trunk extensor endurance test [25]. Lamoth et al [45] showed that the fear of pain altered muscle activity during gait, with a decrease of the erector spinae sEMG mean amplitude. Thus, the identification of the nonspecific chronic LBP subgroups should be based on the multifactorial parameters (ie, biomechanical, physical, and psychosocial data) linked to nonspecific chronic LBP.

\section{Aim}

This study aims to identify the subgroups of nonspecific chronic LBP patients based on a multifactorial approach, including biomechanical, physical, and psychosocial data.

\section{Methods}

\section{Study Design}

This is a prospective study approved by the Research Ethic Cantonal Commission of the University Hospitals of Geneva (HUG) with reference CER: 14-126. All study data and human material will be handled confidentially and coded with a unique study number. Only the research team will have access to the data.

\section{Participants}

The study population consists of 18- to 60-year old adults from the Geneva area and is divided into 2 groups, namely patients suffering from nonspecific chronic LBP (LBP group) and healthy participants (control group). Both groups will be evaluated in the Willy Taillard Laboratory of Kinesiology of the HUG. Patients will be recruited from the Division of Rheumatology and the Division of Orthopaedic and Trauma Surgery of the HUG.

The patient inclusion criteria are as follows; (1) suffering from nonspecific chronic LBP, (2) duration of at least 3 months, (3) pain intensity over $3 / 10$ on a visual analogical scale, (4) aged between 18 and 60 years, (5) no pain on other parts of the body (except irradiation of nonspecific chronic LBP), and (6) no specific pathology such as infection, tumor, osteoporosis, fracture, structural deformity, inflammatory disorder (eg, ankylosing spondylitis), radicular syndrome, and cauda equina syndrome. The healthy participant inclusion criteria are as follows; (1) aged between 18 and 60 years, (2) no back pain for at least 6 months, and (3) no pain in any part of the body.

The subjects who present with a history of back surgery, a body mass index over $30 \mathrm{~kg} / \mathrm{m}^{2}$, inability to understand French, and pregnancy will be excluded from both groups. All participants included in our study will provide written informed consent to participate.

\section{Sample Size}

The sample size calculation was computed using GPower software (Heinrich Heine University, Dusseldorf, Germany) [46]. This calculation was based on previous studies which identified 2 nonspecific chronic LBP subgroups from sEMG and posture variables. Dankaerts et al [20] found greater lumbar multifidus activity during slumped sitting among the control group ( $n=34)$, pooled nonspecific chronic LBP group $(n=33)$, and within 2 subgroups of nonspecific chronic LBP ( $n=20$ and $\mathrm{n}=13$ ). Meanwhile, Astfalck et al [47] found a difference between the upper lumbar angle in the sitting posture of the control group $(n=28)$ and the 2 nonspecific chronic LBP subgroups $(n=13$ and $n=15)$. The number of participants per group should be between 17 to 21 for comparison with healthy participants and between 27 to 32 for each nonspecific chronic LBP subgroup for differentiation between 2 and 3 subgroups with a statistic power up to $80 \%$ and a $5 \%$ alpha error. Therefore, we will include 100 nonspecific chronic LBP patients and 30 healthy participants.

\section{Data Collection}

\section{Task Description}

The International Classification of Functioning (ICF) defines the typical spectrum of problems in the functioning of patients with LBP and highlights the main areas and functions of interest in the study of LBP [48]. On the basis of the short version of ICF [49], the physical capacities of the patient will be assessed by assessing the flexibility of the hips in flexion and extension, the lumbar spine in flexion, the thoracolumbar segment in lateral flexion, and the trunk extensor and flexor muscle endurance. Functional abilities will be assessed from daily life activities such as gait, object lifting, forward bending, STS (and the reverse), balance, and usual posture (standing and sitting). Kinematics, kinetics, and sEMG will be assessed during the execution of these functional tasks.

\section{Trunk Muscle Endurance}

The Sorensen test, which is considered as the gold standard for this measure [50], will be performed to determine trunk extensor endurance [51,52]. The participants will lie on the examining table in a prone position with the upper edge of their iliac crests' aligned along the edge of the table. The lower body will be fixed to the table by 3 straps located at the level of the pelvis, knees, and ankles. Meanwhile, the Shirado test will be performed to determine trunk flexor endurance [53]. The participants will lie on the examining table in a supine position and will raise their lower extremities until their scapulas' are off the table with a $90^{\circ}$ flexion of the hip and knee joints. These tests are considered valid, safe, reliable, and easy to perform in participants with and without nonspecific chronic LBP [54,55]. Participants' arms are folded across the chest for the duration of both trunk muscle endurance tests. Note that the participants will be asked to hold the original positions for as long as possible, but not exceeding a $240 \mathrm{~s}$ time limit. A $15 \mathrm{~min}$ rest is allowed between the two endurance tests.

\section{Trunk and Hip Flexibility}

The hip and trunk muscles flexibility in the nonspecific chronic LBP population will be evaluated using the straight leg raise test, the Thomas test, and the finger-tip-to-thigh test. These are valid, reliable, and largely used tests. The tests will assess hamstring flexibility [17,56-58], hip flexor flexibility (psoas-iliacus and rectus femoris) [59-62], and measure the lateral trunk range of motion [63,64]. All flexibility tests will be performed according to the methods set out by Norkin and White [65]. 


\section{Balance}

Participants' balance in standing and sitting postures will be evaluated. For the sitting condition which limits the influence of the lower limb, the participants will be seated on an adjustable stool with the middle of the thighs on the edge of the stool and with their feet dangling. For the standing posture, the participants will stand with $10 \mathrm{~cm}$ between their heels and a self-selected angle between the feet [66]. For both postures, the participants must make sure their trunk is erect, fix their head in a neutral position, look ahead, keep arms along the trunk, and move as little as possible. The participants will stand on a force plate and their balance will be assessed under 4 conditions with 3 repeated trials of $30 \mathrm{~s}$ per condition. The conditions under which the balance of the participant will be assessed are eyes closed or opened, with stable or unstable support. To create the unstable support an Airex balance pad $(50 \mathrm{~cm}$ length $\times 41 \mathrm{~cm}$ width $\times 6 \mathrm{~cm}$ thickness) will be used. The condition with the eyes closed are used to avoid visual compensations [67] and unstable conditions are used to challenge the participants' balance [68].

\section{Usual Postures}

The usual sitting and standing postures of each participant will be evaluated. For the sitting posture evaluation, an adjustable stool will be placed on a force plate and the participants will be asked to be seated in a self-selected position with their feet on another force plate. The stool height will be adjusted for each participant to fix the hip and knee flexion at $90^{\circ}$. For the usual standing posture evaluation, the participants will be asked to stand in a self-selected upright position with both feet on the same force plate. For both these usual static postures, the participants will look ahead, and the kinematic will be recorded for $10 \mathrm{~s}$ in the posture.

\section{Gait}

The participants will be asked to walk barefoot at 3 different speeds (ie, self-selected, fast, and slow) along a $10 \mathrm{~m}$ walkway to assess their gait. Data will be collected for at least 10 gait cycles for each participant and the speed will be monitored.

\section{Lifting Task}

Two lifting tasks will be performed. For both tasks, the participants will start on a force plate in an upright standing position, bend down to lift a box and return to an upright standing position with $90^{\circ}$ flexion of elbows holding the box. They will maintain this posture for $4 \mathrm{~s}$, and then bend down to place the box to the ground before returning to the initial posture. This test will be performed under two conditions. The first condition is a usual lift, where the participants are asked to lift the box with a self-selected strategy, and no more instruction will be given [69]. The second condition is a standardized lift based on deadlift methods [70]. This will be used to compare the muscle strategies for the same movement between the subjects. The usual lift will be performed before the standardized lift to avoid behavioral adaptations.

Three trials will be performed per condition with 2 min rest between each condition. The weight of the box will be adjusted to $10 \%$ of the participant's weight for each condition. The participant will be instructed to stay on the force plate for the duration of the test.

\section{Trunk Forward Bending}

The participants will start standing in an upright position (standing phase), flex the trunk as far forward as possible with their knees extended (flexion phase), maintain this trunk full-flexion position (full flexion phase), and then return to an upright standing position (extension phase). Each phase will last for $4 \mathrm{~s}$, and an audible metronome will be used to regulate the movement timing. Three trials will be performed, and only the second trial will be used for analysis [71].

\section{Sit-to-Stand}

The STS tasks will be performed under the following three conditions: (1) usual STS, (2) standardized STS, and (3) 5 consecutive STSs. In the usual condition, the participants will sit in a self-selected position on a stool placed on a force plate with their feet placed on another force plate. No more instructions on posture will be given for this condition. In the standardized STS, the participants will be barefoot and asked to sit upright on an adjustable stool with their trunk straight and arms crossed on the chest. The stool will be placed on a force plate, the participant's feet will be placed on a second force plate, and the stool height will be adjusted for each participant to fix the hip and knee flexion at $90^{\circ}$ in the starting position.

For both the usual STS and standardized STS, the participants will stand up after $4 \mathrm{~s}$ of sitting, maintain the upright standing position with knees fully extended for $4 \mathrm{~s}$, return to the initial sitting position, and maintain it for $4 \mathrm{~s}$. Three trials will be performed for both the STS and standardized STS tasks.

The 5 consecutive STS task provides information on the global capacity of the participant to perform the STS task. The participants will have the same start position as the standardized STS task. The participants will then be asked to perform 5 consecutive STS movements as fast as possible. As a precautionary measure, an investigator will stand near the participant to prevent possible falls. To evaluate the total task duration, the start and end points of the task will be defined by the mean value of the anterior-posterior center of the pressure displacement during the usual sitting phase before and after the task was completed [72].

\section{Psychosocial Profile}

The psychosocial profile will be explored using patient-reported outcomes to evaluatef anxiety, depression, functional disability, fear of pain, avoidance belief, and physical activity (PA). All the questionnaires will be self-completed before the experiments, except for the PA questionnaire which will be completed by the investigator with the participant during the course of the experiments.

\section{Anxiety and Depression}

Anxiety and depression are parameters which play an important role in the sustainability of pain; hence, they are factors of pain chronicity [42]. The Hospital Anxiety and Depression Scale (HADS) [73] is widely used to evaluate mental disorders [74] in the LBP population [75]. This study will use the French version of the HADS introduced by Lépine et al [76], which 
has been used in other studies conducted on French-speaking populations [77-79].

\section{Functional Capacity}

The functional capacity evaluation is recommended when studying LBP [80]. Functional capacity is indeed an interesting parameter to evaluate the interference of pain on daily life [81]. One of the most used and recognized assessment tools is the Oswestry Disability Questionnaire (ODI) [82], which is specific for LBP [83]. The French validated version of the ODI [84] will be used for this study.

\section{Pain Catastrophizing}

A systematic review shows that pain catastrophizing can predict the degree of pain, disability, and mediated treatment efficacy in the nonspecific chronic LBP population [85]. The pain catastrophizing scale (PCS) was introduced by Sullivan et al [86], and his validated French version [87] will be used for this study.

\section{Fear and Belief}

Fear avoidance beliefs are reported to be factors for the delayed recovery and chronicity of pain in the nonspecific chronic LBP population [88]. One of the questionnaires used to identify fear avoidance beliefs is the Fear Avoidance Beliefs Questionnaire (FABQ) [89]. This study will use the French version of the FABQ validated by Chaory et al [90].

\section{Physical Activity}

PA plays an important role in the prevention of nonspecific chronic LBP. The participant's weekly PA will be assessed using the Global Physical Activity Questionnaire (GPAQ) developed by the World Health Organization [91]. This questionnaire has already been used in studies on the nonspecific chronic LBP population [92].

\section{Pain}

Pain is a key symptom in nonspecific chronic LBP, therefore, its evaluation during the course of the study is recommended $[49,93]$. The intensities of current pain, pain in the last $24 \mathrm{~h}$, pain in the last week, pain in the last month, and pain in the last 3 months will be quantified with a visual analogue scale largely used in the nonspecific chronic LBP population [29,94-96].

\section{Materials and Parameters}

\section{Electromyographic Activity}

The sEMG will be bilaterally collected from 3 back muscles (ie, lumbar multifidus, iliocostalis lumborum, and lumbar erector spinae), 2 abdominal muscles (ie, transverse fibers of the abdominal external oblique and rectus abdominus), gluteus medius, semitendinosus, and the rectus femoris muscle. Moreover, 16 active surface electrodes (model: Trigno, Delsys Inc, Boston, MA, USA) will be used to collect the sEMG signals at a sampling frequency of $1000 \mathrm{~Hz}$. The skin at the electrode sites will be shaved, abraded, and cleaned with alcohol prior to measurement. The electrodes will then be positioned relative to the muscle fiber direction, following the surface EMG for noninvasive assessment of muscles project recommendations [97].
The sEMG activation pattern, time of cocontraction (TCC), and cocontraction index (CCI) [98] will be calculated for gait, STS, and lift tasks. The TCC is the time for simultaneous activation of a pair of muscle groups over a specified number of data points (activation thresholdbaseline+3 SD; duration activity threshold: $5 \mathrm{~ms}$ ) [99]. The CCI is defined as the degree of coactivation for a pair of muscle groups over a specified number of data points. The TTC and CCI will characterize muscle coordination. The flexion-relaxation ratio will be calculated and used to detect and quantify exacerbated back muscle activity for trunk forward bending [71]. The muscle fatigability of the back and abdomen muscles will be evaluated using the sEMG median frequency evolution during endurance tasks [100].

\section{Kinematics}

The kinematic parameters will be recorded using a 12-camera motion analysis system (Oqus7+, Qualisys, Göteborg, Sweden) set at a sampling frequency of $100 \mathrm{~Hz}$. The participants will have 35 reflective markers ( $14 \mathrm{~mm}$ diameter) placed on the skin at defined anatomical and technical landmarks on the head, trunk, and pelvis and bilaterally on the arms, thighs, shanks, and feet according to the full-body Plug-in-Gait model [101]. Additional markers will be placed on the spinous process of $\mathrm{T} 2$, T4, T6, T8, L1, L3, L5, and S1 to assess the sagittal plane curve of the spine [102,103].

The thorax, lumbar, pelvis, hip, knee, and ankle kinematics (maximum angle, range of motion, and speed) will be calculated in 3 planes for all tasks. The lumbar/hip ratio will be calculated for the trunk forward bending, STS, and lift tasks [104,105]. The relative phase between the pelvis and the thorax segment and the spatiotemporal parameters (ie, walking speed, cadence, stance phase, and step length) will be calculated during gait [106]. The thorax movement during the balance tasks will characterize the trunk sway [107].

\section{Kinetics}

Two force plates (AMTI Accugait, Watertown, NY, USA) at a sampling frequency of $1000 \mathrm{~Hz}$ will be used to measure the ground reaction forces. The center of pressure displacement (range and speed) will be calculated for the balance tasks to assess the balance capacity $[68,108,109]$. All kinetic, kinematic, and sEMG data will be synchronized together.

\section{Experimental Procedure}

To introduce the study, a phone interview will be conducted by the investigator after nonspecific chronic LBP is diagnosed by a spinal consultant. An information letter will be sent to the patient (by email or post) once he/she agrees to voluntarily participate in this study. An appointment time will then be scheduled. Upon arrival, the participants will complete the HADS, ODI, and PCS questionnaires. The GPAQ and Pain Evaluation will be completed by the investigator during the interview with the participant. All sEMG sensors will be placed after skin preparation as outlined above. The participants will then perform the flexor endurance, extensor endurance, and flexibility tests. Next, the reflective markers will be placed, and the participants will perform the functional tasks in the order listed above with a minimum rest period of $3 \mathrm{~min}$ between each task. A pain assessment will be made after each task to quantify 
the pain generated by the task, using current pain as a reference. per participant.

The total duration of this protocol (Figure 1) will be $120 \mathrm{~min}$

Figure 1. Flow diagram of the study. FABQ: fear-avoidance belief questionnaire; HADS: Hospital Anxiety and Depression Scale; NSCLBP: nonspecific chronic low back pain; ODI: Oswestry Disability Index; PA: physical activity; PCS: pain catastrophizing scale; sEMG: surface electromyography.

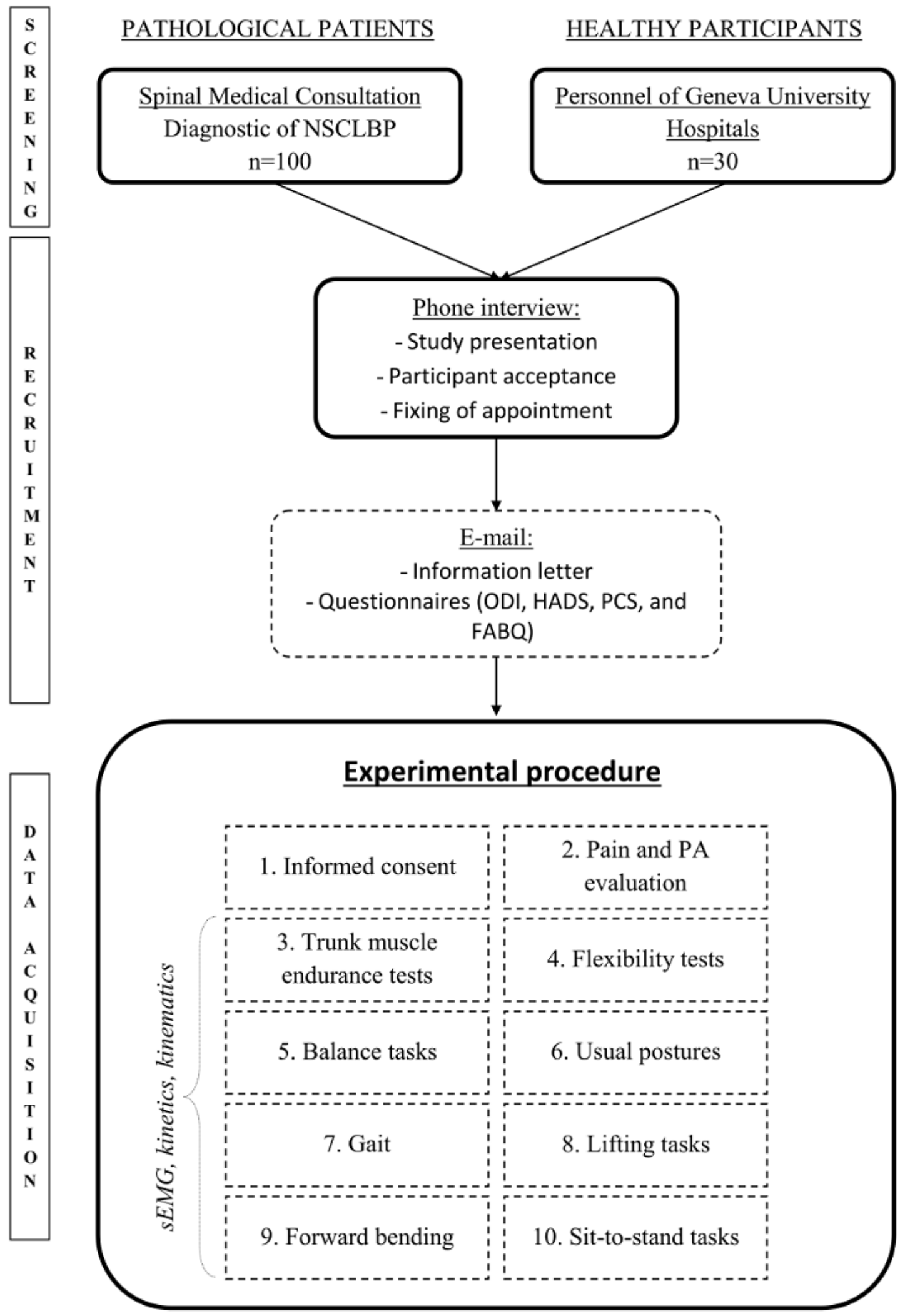




\section{Data Analysis}

The joint kinematics and kinetics data will be computed using Visual3D (C-Motion, Inc, Germantown, MD, USA). Data extraction will be performed using MATLAB R2015b (MathWorks, USA) and the open-source Biomechanical ToolKit package for MATLAB [110]. R software v.3.1.3 will be used for all statistical analyses. Data will be reduced with principal component analysis. Meanwhile, $K$-mean or descending hierarchical clustering classification methods will be used to identify the nonspecific chronic LBP subgroups. The clustering classification methods will be determined according to the data. In addition, a statistical inference test (parametric or nonparametric depending on the normality of the data distribution) will be applied to compare the nonspecific chronic LBP patients with healthy participants and to compare the different patient subgroups $(P<.05)$.

\section{Results}

The data collection started in September 2017 and will be completed with the inclusion of all the participants (100 nonspecific chronic LBP patients and 30 controls). The study results will be published in peer-reviewed journals and presented at relevant international conferences.

\section{Discussion}

\section{Principal Consideration}

This study presents originality and the opportunity to connect large amounts of data about different features of various conditions with the same population sample. The results should allow for a better understanding of nonspecific LBP. The perspective of this study is expected to support clinicians for more adapted therapeutic management for each subgroup. Furthermore, this study could provide a reference protocol for functional tasks when nonspecific chronic LBP is studied.

\section{Limitations}

A limitation of this study could include missing data from the participant and/or to the materials used in the study. For example, a nonspecific chronic LBP patient may not be able to perform all the tasks required because of their functional capacity or pain level. An example of missing data from the study material could include the fact that surface EMG may contain artifacts that alter analysis of the muscle activity. Moreover, patients will be recruited from the Orthopedic and Rheumatology service of Geneva University Hospital, which limits generalization of the results to the global nonspecific chronic LBP population. Finally, because previous studies have found two nonspecific chronic LBP subgroups, three subgroups were used for the sample size calculation to ensure that at least two subgroups could be found, but more groups may be found in the clustering analysis.

\section{Conclusions}

Therapeutic management of nonspecific chronic LBP is rather difficult and has inconstant effects because of the complexity of nonspecific chronic LBP and the heterogeneity of nonspecific chronic LBP patients. Identifying subgroups in the nonspecific chronic LBP population represents benefit interests and a challenge both clinically and socially. This study aims to identify subgroups in nonspecific chronic LBP participants which include biomechanical, physical, and psychosocial factors to enhance the targeted therapy.

\section{Acknowledgments}

This work was partly supported by the French National Research Agency in the framework of the "Investissements d'Avenir" program (ANR-15-IDEX-02) and by Institut Universitaire de France.

\section{Conflicts of Interest}

None declared.

\section{References}

1. Global Burden of Disease Study 2013 Collaborators. Global, regional, and national incidence, prevalence, and years lived with disability for 301 acute and chronic diseases and injuries in 188 countries, 1990-2013: a systematic analysis for the Global Burden of Disease Study 2013. Lancet 2015 Aug 22;386(9995):743-800 [FREE Full text] [doi: 10.1016/S0140-6736(15)60692-4] [Medline: 26063472]

2. Balagué F, Mannion AF, Pellisé F, Cedraschi C. Non-specific low back pain. Lancet 2012 Feb 04;379(9814):482-491. [doi: 10.1016/S0140-6736(11)60610-7] [Medline: 21982256]

3. van Tulder M, Becker A, Bekkering T, Breen A, del Real MT, Hutchinson A, COST B13 Working Group on Guidelines for the Management of Acute Low Back Pain in Primary Care. Chapter 3. European guidelines for the management of acute nonspecific low back pain in primary care. Eur Spine J 2006 Mar 15;15(Suppl 2):S169-S191 [FREE Full text] [doi: 10.1007/s00586-006-1071-2] [Medline: 16550447]

4. Andersson GB. Epidemiological features of chronic low-back pain. Lancet 1999 Aug 14;354(9178):581-585. [doi: 10.1016/S0140-6736(99)01312-4] [Medline: 10470716]

5. Koes BW, van Tulder M, Lin CC, Macedo LG, McAuley J, Maher C. An updated overview of clinical guidelines for the management of non-specific low back pain in primary care. Eur Spine J 2010 Dec;19(12):2075-2094 [FREE Full text] [doi: 10.1007/s00586-010-1502-y] [Medline: 20602122] 
6. Waldburger M, Stucki RF, Balagué F, Wittig R. [Early multidisciplinary approach in lumbar pain to prevent development of chronicity]. Rev Med Suisse Romande 2001 Aug;121(8):581-584. [Medline: 11565220]

7. Ma VY, Chan L, Carruthers KJ. Incidence, prevalence, costs, and impact on disability of common conditions requiring rehabilitation in the United States: stroke, spinal cord injury, traumatic brain injury, multiple sclerosis, osteoarthritis, rheumatoid arthritis, limb loss, and back pain. Arch Phys Med Rehabil 2014 May;95(5):986-95.e1 [FREE Full text] [doi: 10.1016/j.apmr.2013.10.032] [Medline: 24462839]

8. Wieser S, Horisberger B, Schmidhauser S, Eisenring C, Brügger U, Ruckstuhl A, et al. Cost of low back pain in Switzerland in 2005. Eur J Health Econ 2011 Oct 12;12(5):455-467 [FREE Full text] [doi: 10.1007/s10198-010-0258-y] [Medline: 20526649]

9. Depont F, Hunsche E, Abouelfath A, Diatta T, Addra I, Grelaud A, et al. Medical and non-medical direct costs of chronic low back pain in patients consulting primary care physicians in France. Fundam Clin Pharmacol 2010 Feb;24(1):101-108. [doi: 10.1111/j.1472-8206.2009.00730.x] [Medline: 19678853]

10. Jäger M, Griefhan B, Luttman A. World Health Organization. 2004. La prévention des troubles musculo-squelettiques sur le lieu de travail URL: http://www.who.int/occupational health/publications/en/pwh5f.pdf [accessed 2018-03-22] [WebCite Cache ID 6y6hsxmFQ]

11. Deyo RA, Weinstein JN. Low back pain. N Engl J Med 2001 Feb 01;344(5):363-370. [doi: 10.1056/NEJM200102013440508] [Medline: 11172169$]$

12. Krismer M, van Tuldor M, Low Back Pain Group of the BoneJoint Health Strategies for Europe Project. Strategies for prevention and management of musculoskeletal conditions. Low back pain (non-specific). Best Pract Res Clin Rheumatol 2007 Feb;21(1):77-91. [doi: 10.1016/j.berh.2006.08.004] [Medline: 17350545]

13. Airaksinen O, Brox JI, Cedraschi C, Hildebrandt J, Klaber-Moffett J, Kovacs F, COST B13 Working Group on Guidelines for Chronic Low Back Pain. Chapter 4. European guidelines for the management of chronic nonspecific low back pain. Eur Spine J 2006 Mar;15 Suppl 2:S192-S300 [FREE Full text] [doi: 10.1007/s00586-006-1072-1] [Medline: 16550448]

14. Chiarotto A, Deyo RA, Terwee CB, Boers M, Buchbinder R, Corbin TP, et al. Core outcome domains for clinical trials in non-specific low back pain. Eur Spine J 2015 Jun;24(6):1127-1142. [doi: 10.1007/s00586-015-3892-3] [Medline: 25841358]

15. Waddell G. The Back Pain Revolution. London: Churchill Livingstone; 2004:1-948.

16. Balagué F, Ochoa Amaya G, Genevay S. [Conservative treatment of chronic low back pain: what is new in 2008 ?]. Rev Med Suisse 2009 Mar 11;5(194):560-2, 564. [Medline: 19405270]

17. Hayden JA, Cartwright JL, Riley RD, Vantulder MW, Chronic Low Back Pain IPD Meta-Analysis Group. Exercise therapy for chronic low back pain: protocol for an individual participant data meta-analysis. Syst Rev 2012 Dec 21;1:64 [FREE Full text] [doi: 10.1186/2046-4053-1-64] [Medline: 23259855]

18. Kent P, Keating J. Do primary-care clinicians think that nonspecific low back pain is one condition? Spine (Phila Pa 1976) 2004 May 01;29(9):1022-1031. [Medline: 15105677]

19. Leboeuf-Yde C, Lauritsen JM, Lauritzen T. Why has the search for causes of low back pain largely been nonconclusive? Spine (Phila Pa 1976) 1997 Apr 15;22(8):877-881. [Medline: 9127921]

20. Dankaerts W, O'Sullivan P, Burnett A, Straker L. Altered patterns of superficial trunk muscle activation during sitting in nonspecific chronic low back pain patients: importance of subclassification. Spine (Phila Pa 1976) 2006 Aug 01;31(17):2017-2023. [doi: 10.1097/01.brs.0000228728.11076.82] [Medline: 16924221]

21. Kent P, Keating JL, Leboeuf-Yde C. Research methods for subgrouping low back pain. BMC Med Res Methodol 2010 Jul 03;10:62 [FREE Full text] [doi: 10.1186/1471-2288-10-62] [Medline: 20598153]

22. Billis E, McCarthy CJ, Roberts C, Gliatis J, Papandreou M, Gioftsos G, et al. Sub-grouping patients with non-specific low back pain based on cluster analysis of discriminatory clinical items. J Rehabil Med 2013 Feb;45(2):177-185 [FREE Full text] [doi: 10.2340/16501977-1100] [Medline: 23321847]

23. Kalichman L, Hunter DJ. The genetics of intervertebral disc degeneration. Familial predisposition and heritability estimation. Joint Bone Spine 2008 Jul;75(4):383-387. [doi: 10.1016/j.jbspin.2007.11.003] [Medline: 18448379]

24. Reimann F, Cox JJ, Belfer I, Diatchenko L, Zaykin DV, McHale DP, et al. Pain perception is altered by a nucleotide polymorphism in SCN9A. Proc Natl Acad Sci U S A 2010 Mar 16;107(11):5148-5153 [FREE Full text] [doi: 10.1073/pnas.0913181107] [Medline: 20212137]

25. Larivière C, Bilodeau M, Forget R, Vadeboncoeur R, Mecheri H. Poor back muscle endurance is related to pain catastrophizing in patients with chronic low back pain. Spine (Phila Pa 1976) 2010 Oct 15;35(22):E1178-E1186. [doi: 10.1097/BRS.0b013e3181e53334] [Medline: 20881658]

26. Demoulin C, Crielaard JM, Vanderthommen M. Spinal muscle evaluation in healthy individuals and low-back-pain patients: a literature review. Joint Bone Spine 2007 Jan;74(1):9-13. [doi: 10.1016/j.jbspin.2006.02.013] [Medline: 17174584]

27. Radwan A, Bigney KA, Buonomo HN, Jarmak MW, Moats SM, Ross JK, et al. Evaluation of intra-subject difference in hamstring flexibility in patients with low back pain: an exploratory study. J Back Musculoskelet Rehabil 2014 Jun 24. [doi: 10.3233/BMR-140490] [Medline: 24968796]

28. Laird RA, Gilbert J, Kent P, Keating JL. Comparing lumbo-pelvic kinematics in people with and without back pain: a systematic review and meta-analysis. BMC Musculoskelet Disord 2014 Jul 10;15:229 [FREE Full text] [doi: 10.1186/1471-2474-15-229] [Medline: 25012528] 
29. Müller R, Ertelt T, Blickhan R. Low back pain affects trunk as well as lower limb movements during walking and running. J Biomech 2015 Apr 13;48(6):1009-1014. [doi: 10.1016/j.jbiomech.2015.01.042] [Medline: 25700607]

30. Lamoth CJ, Meijer OG, Daffertshofer A, Wuisman PI, Beek PJ. Effects of chronic low back pain on trunk coordination and back muscle activity during walking: changes in motor control. Eur Spine J 2006 Jan;15(1):23-40 [FREE Full text] [doi: 10.1007/s00586-004-0825-y] [Medline: 15864670$]$

31. Shum GL, Crosbie J, Lee RY. Effect of low back pain on the kinematics and joint coordination of the lumbar spine and hip during sit-to-stand and stand-to-sit. Spine (Phila Pa 1976) 2005 Sep 01;30(17):1998-2004. [Medline: 16135992]

32. Christe G, Redhead L, Legrand T, Jolles BM, Favre J. Multi-segment analysis of spinal kinematics during sit-to-stand in patients with chronic low back pain. J Biomech 2016 Dec 05;49(10):2060-2067. [doi: 10.1016/j.jbiomech.2016.05.015] [Medline: 27262182]

33. Rudy TE, Boston RJ, Lieber SJ, Kubinski JA, Stacey BR. Body motion during repetitive isodynamic lifting: a comparative study of normal subjects and low-back pain patients. Pain 2003;105(1):319-326. [doi: 10.1016/S0304-3959(03)00247-1]

34. Seay JF, Sauer SG, Frykman PN, Roy TC. A history of low back pain affects pelvis and trunk mechanics during a sustained lift/lower task. Ergonomics 2013;56(6):944-953. [doi: 10.1080/00140139.2013.781234] [Medline: 23586619]

35. Ghamkhar L, Kahlaee AH. Trunk muscles activation pattern during walking in subjects with and without chronic low back pain: a systematic review. PM R 2015 May;7(5):519-526. [doi: 10.1016/j.pmrj.2015.01.013] [Medline: 25633636]

36. Falla D, Gizzi L, Tschapek M, Erlenwein J, Petzke F. Reduced task-induced variations in the distribution of activity across back muscle regions in individuals with low back pain. Pain 2014 May;155(5):944-953. [doi: 10.1016/j.pain.2014.01.027] [Medline: 24502841]

37. Geisser ME, Ranavaya M, Haig AJ, Roth RS, Zucker R, Ambroz C, et al. A meta-analytic review of surface electromyography among persons with low back pain and normal, healthy controls. J Pain 2005 Nov;6(11):711-726. [doi: 10.1016/j.jpain.2005.06.008] [Medline: 16275595]

38. Kim MH, Yoo WG, Choi BR. Differences between two subgroups of low back pain patients in lumbopelvic rotation and symmetry in the erector spinae and hamstring muscles during trunk flexion when standing. J Electromyogr Kinesiol 2013 Apr;23(2):387-393. [doi: 10.1016/j.jelekin.2012.11.010] [Medline: 23295146]

39. Schinkel-Ivy A, Nairn BC, Drake JD. Quantification of the lumbar flexion-relaxation phenomenon: comparing outcomes of lumbar erector spinae and superficial lumbar multifidus in standing full trunk flexion and slumped sitting postures. J Manipulative Physiol Ther 2014 Sep;37(7):494-501. [doi: 10.1016/j.jmpt.2014.07.003] [Medline: 25109838]

40. Slaboda JC, Boston JR, Rudy TE, Lieber SJ. Classifying subgroups of chronic low back pain patients based on lifting patterns. Arch Phys Med Rehabil 2008 Aug;89(8):1542-1549. [doi: 10.1016/j.apmr.2008.01.016] [Medline: 18674989]

41. Dankaerts W, O'Sullivan P, Burnett A, Straker L, Davey P, Gupta R. Discriminating healthy controls and two clinical subgroups of nonspecific chronic low back pain patients using trunk muscle activation and lumbosacral kinematics of postures and movements: a statistical classification model. Spine (Phila Pa 1976) 2009 Jul 01;34(15):1610-1618. [doi: 10.1097/BRS.0b013e3181aa6175] [Medline: 19564772]

42. Linton SJ, Shaw WS. Impact of psychological factors in the experience of pain. Phys Ther 2011 May;91(5):700-711. [doi: 10.2522/ptj.20100330] [Medline: 21451097]

43. Shaw WS, Hartvigsen J, Woiszwillo MJ, Linton SJ, Reme SE. Psychological distress in acute low back pain: a review of measurement scales and levels of distress reported in the first 2 months after pain onset. Arch Phys Med Rehabil 2016 Dec;97(9):1573-1587. [doi: 10.1016/j.apmr.2016.02.004] [Medline: 26921683]

44. Butler HL, Lariviere C, Hubley-Kozey CL, Sullivan MJ. Directed attention alters the temporal activation patterns of back extensors during trunk flexion-extension in individuals with chronic low back pain. Eur Spine J 2010 Sep;19(9):1508-1516 [FREE Full text] [doi: 10.1007/s00586-010-1403-0] [Medline: 20473625]

45. Lamoth CJ, Daffertshofer A, Meijer OG, Lorimer Moseley MG, Wuisman PI, Beek PJ. Effects of experimentally induced pain and fear of pain on trunk coordination and back muscle activity during walking. Clin Biomech (Bristol, Avon) 2004 Jul;19(6):551-563. [doi: 10.1016/j.clinbiomech.2003.10.006] [Medline: 15234478]

46. Faul F, Erdfelder E, Lang A, Buchner A. G*Power 3: a flexible statistical power analysis program for the social, behavioral, and biomedical sciences. Behav Res Methods 2007 May;39(2):175-191. [Medline: 17695343]

47. Astfalck RG, O'Sullivan PB, Straker LM, Smith AJ, Burnett A, Caneiro JP, et al. Sitting postures and trunk muscle activity in adolescents with and without nonspecific chronic low back pain: an analysis based on subclassification. Spine (Phila Pa 1976) 2010 Jun 15;35(14):1387-1395. [doi: 10.1097/BRS.0b013e3181bd3ea6] [Medline: 20195206]

48. World Health Organisation. 2001. International classification of functioning, disability and health internet URL: http://www. who.int/classifications/icf/en/ [accessed 2018-03-22] [WebCite Cache ID 6y6q3oddX]

49. Cieza A, Stucki G, Weigl M, Disler P, Jäckel W, van der Linden S, et al. ICF Core Sets for low back pain. J Rehabil Med 2004 Jul(44 Suppl):69-74 [FREE Full text] [doi: 10.1080/16501960410016037] [Medline: 15370751]

50. Müller R, Strässle K, Wirth B. Isometric back muscle endurance: an EMG study on the criterion validity of the Ito test. J Electromyogr Kinesiol 2010 Oct;20(5):845-850. [doi: 10.1016/j.jelekin.2010.04.004] [Medline: 20471284]

51. Biering-Sørensen F. Physical measurements as risk indicators for low-back trouble over a one-year period. Spine (Phila Pa 1976) 1984 Mar;9(2):106-119. [Medline: 6233709] 
52. Demoulin C, Vanderthommen M, Duysens C, Crielaard J. Spinal muscle evaluation using the Sorensen test: a critical appraisal of the literature. Joint Bone Spine 2006 Jan;73(1):43-50. [doi: 10.1016/j.jbspin.2004.08.002] [Medline: 16461206]

53. Ito T, Shirado O, Suzuki H, Takahashi M, Kaneda K, Strax TE. Lumbar trunk muscle endurance testing: an inexpensive alternative to a machine for evaluation. Arch Phys Med Rehabil 1996 Jan;77(1):75-79. [Medline: 8554479$]$

54. Calmels P, Jacob JF, Fayolle-Minon I, Charles C, Bouchet JP, Rimaud D, et al. [Use of isokinetic techniques vs standard physiotherapy in patients with chronic low back pain. Preliminary results]. Ann Readapt Med Phys 2004 Feb;47(1):20-27. [doi: 10.1016/j.annrmp.2003.07.001] [Medline: 14967569]

55. Evans K, Refshauge KM, Adams R. Trunk muscle endurance tests: reliability, and gender differences in athletes. J Sci Med Sport 2007 Dec;10(6):447-455. [doi: 10.1016/j.jsams.2006.09.003] [Medline: 17141568]

56. Miller ER, Schenk RJ, Karnes JL, Rousselle JG. A comparison of the Mckenzie approach to a specific spine stabilization program for chronic low back pain. J Man Manip Ther 2013 Jul 18;13(2):103-112. [doi: 10.1179/106698105790824996]

57. Shum GL, Crosbie J, Lee RY. Energy transfer across the lumbosacral and lower-extremity joints in patients with low back pain during sit-to-stand. Arch Phys Med Rehabil 2009 Jan;90(1):127-135. [doi: 10.1016/j.apmr.2008.06.028] [Medline: 19154839]

58. Corkery MB, O’Rourke B, Viola S, Yen SC, Rigby J, Singer K, et al. An exploratory examination of the association between altered lumbar motor control, joint mobility and low back pain in athletes. Asian J Sports Med 2014 Nov 01;6(1):e24283. [doi: 10.5812/asjsm.24283] [Medline: 25741418]

59. Winters MV, Blake CG, Trost JS, Marcello-Brinker TB, Lowe LM, Garber MB, et al. Passive versus active stretching of hip flexor muscles in subjects with limited hip extension: a randomized clinical trial. Phys Ther 2004 Sep;84(9):800-807. [Medline: 15330693]

60. Handrakis JP, Friel K, Hoeffner F, Akinkunle O, Genova V, Isakov E, et al. Key characteristics of low back pain and disability in college-aged adults: a pilot study. Arch Phys Med Rehabil 2012 Jul;93(7):1217-1224. [doi: 10.1016/j.apmr.2012.02.013] [Medline: 22516875]

61. Hislop H, Avers D, Brown M. Daniels and Worthingham's Muscle Testing. Techniques of Manual Examination and Performance Testing. Saintt-Louis: Elsevier saunders; 2013.

62. Avrahami D, Potvin JR. The clinical and biomechanical effects of fascial-muscular lengthening therapy on tight hip flexor patients with and without low back pain. J Can Chiropr Assoc 2014 Dec;58(4):444-455 [FREE Full text] [Medline: 25550670]

63. Mellin GP. Accuracy of measuring lateral flexion of the spine with a tape. Clin Biomech (Bristol, Avon) 1986 May;1(2):85-89. [doi: 10.1016/0268-0033(86)90081-1] [Medline: 23906359]

64. Lindell O, Eriksson L, Strender LE. The reliability of a 10-test package for patients with prolonged back and neck pain: could an examiner without formal medical education be used without loss of quality? A methodological study. BMC Musculoskelet Disord 2007 Apr 03;8:31 [FREE Full text] [doi: 10.1186/1471-2474-8-31] [Medline: 17407580]

65. Norkin CC. In: White DJ, editor. Measurement of Joint Motion: A Guide to Goniometry. 4th Revised edition. Philadelphia: F. A. Davis Company; 2009.

66. Brumagne S, Janssens L, Knapen S, Claeys K, Suuden-Johanson E. Persons with recurrent low back pain exhibit a rigid postural control strategy. Eur Spine J 2008 Sep;17(9):1177-1184 [FREE Full text] [doi: 10.1007/s00586-008-0709-7] [Medline: 18594876$]$

67. Murans G, Gutierrez-Farewik EM, Saraste H. Kinematic and kinetic analysis of static sitting of patients with neuropathic spine deformity. Gait Posture 2011;34(4):533-538. [Medline: 21816615]

68. Schelldorfer S, Ernst MJ, Rast FM, Bauer CM, Meichtry A, Kool J. Low back pain and postural control, effects of task difficulty on centre of pressure and spinal kinematics. Gait Posture 2015;41(1):112-118. [Medline: 25270326]

69. Larivière C, Gagnon D, Loisel P. A biomechanical comparison of lifting techniques between subjects with and without chronic low back pain during freestyle lifting and lowering tasks. Clin Biomech 2002 Feb;17(2):89-98. [doi: 10.1016/S0268-0033(01)00106-1]

70. Legeard E. Force: entraînement \& musculation [Strength: Training \& Strength Training]. France: Amphora Publishing; 2005.

71. Schinkel-Ivy A, Nairn BC, Drake JD. Evaluation of methods for the quantification of the flexion-relaxation phenomenon in the lumbar erector spinae muscles. J Manipulative Physiol Ther 2013;36(6):349-358. [doi: 10.1016/j.jmpt.2013.05.017] [Medline: 23845199]

72. Pijnenburg M, Brumagne S, Caeyenberghs K, Janssens L, Goossens N, Marinazzo D, et al. Resting-state functional connectivity of the sensorimotor network in individuals with nonspecific low back pain and the association with the sit-to-stand-to-sit task. Brain Connect 2015 Jun;5(5):303-311. [doi: 10.1089/brain.2014.0309] [Medline: 25557846]

73. Zigmond AS, Snaith RP. The hospital anxiety and depression scale. Acta Psychiatr Scand 1983 Jun;67(6):361-370. [Medline: $\underline{6880820]}$

74. Bjelland I, Dahl AA, Haug TT, Neckelmann D. The validity of the Hospital Anxiety and Depression Scale. An updated literature review. J Psychosom Res 2002 Feb;52(2):69-77. [Medline: 11832252]

75. Turk DC, Dworkin RH, Trudeau JJ, Benson C, Biondi DM, Katz NP, et al. Validation of the hospital anxiety and depression scale in patients with acute low back pain. J Pain 2015 Oct;16(10):1012-1021. [doi: 10.1016/j.jpain.2015.07.001] [Medline: 26208762] 
76. Lépine JP, Godchau M, Brun P, Lempérière T. [Evaluation of anxiety and depression among patients hospitalized on an internal medicine service]. Ann Med Psychol (Paris) 1985 Feb;143(2):175-189. [Medline: 4037594]

77. Savard J, Laberge B, Gauthier JG, Ivers H, Bergeron MG. Evaluating anxiety and depression in HIV-infected patients. J Pers Assess 1998 Dec;71(3):349-367. [doi: 10.1207/s15327752jpa7103_5] [Medline: 9933941]

78. Friedman S, Samuelian J, Lancrenon S, Even C, Chiarelli P. Three-dimensional structure of the Hospital Anxiety and Depression Scale in a large French primary care population suffering from major depression. Psychiatry Res 2001 Nov 30;104(3):247-257. [Medline: 11728614]

79. Untas A, Aguirrezabal M, Chauveau P, Leguen E, Combe C, Rascle N. [Anxiety and depression in hemodialysis: validation of the Hospital Anxiety and Depression Scale (HADS)]. Nephrol Ther 2009 Jun;5(3):193-200. [doi: 10.1016/j.nephro.2009.01.007] [Medline: 19346177]

80. Ehrlich GE, Khaltev NG, World Health Organization, Chronic Respiratory Diseases and Arthritis Team. In: Ehrlich GE, Khaltev NG, editors. Low back pain initiative. Geneva: World Health Organization; 1999.

81. Bombardier C. Outcome assessments in the evaluation of treatment of spinal disorders: summary and general recommendations. Spine (Phila Pa 1976) 2000 Dec 15;25(24):3100-3103. [Medline: 11124724]

82. Fairbank JC, Couper J, Davies JB, O'Brien JP. The Oswestry low back pain disability questionnaire. Physiotherapy 1980 Aug;66(8):271-273. [Medline: 6450426]

83. Calmels P, Béthoux F, Condemine A, Fayolle-Minon I. [Low back pain disability assessment tools]. Ann Readapt Med Phys 2005 Jul;48(6):288-297. [doi: 10.1016/j.annrmp.2005.04.008] [Medline: 15932777]

84. Vogler D, Paillex R, Norberg M, de Goumoëns P, Cabri J. [Cross-cultural validation of the Oswestry disability index in French]. Ann Readapt Med Phys 2008 Jun;51(5):379-385. [doi: 10.1016/j.annrmp.2008.03.006] [Medline: 18501463]

85. Wertli MM, Burgstaller JM, Weiser S, Steurer J, Kofmehl R, Held U. Influence of catastrophizing on treatment outcome in patients with nonspecific low back pain: a systematic review. Spine (Phila Pa 1976) 2014 Feb 01;39(3):263-273. [doi: 10.1097/BRS.0000000000000110] [Medline: 24253796]

86. Sullivan M, Bishop S, Pivik J. APA PsychNET. 1995. The pain catastrophizing scale: development and validation URL: http://psycnet.apa.org/journals/pas/7/4/524/ [accessed 2018-03-22] [WebCite Cache ID 6y6sQHhZH]

87. French DJ, Noël M, Vigneau F, French JA, Cyr CP, Thomas ER. L'Échelle de dramatisation face à la douleur PCS-CF: Adaptation canadienne en langue française de l'échelle «Pain Catastrophizing Scale». Can J Behav Sci 2005 Jul;37(3):181-192. [doi: 10.1037/h0087255]

88. Wertli MM, Rasmussen-Barr E, Weiser S, Bachmann LM, Brunner F. The role of fear avoidance beliefs as a prognostic factor for outcome in patients with nonspecific low back pain: a systematic review. Spine J 2014 May 01;14(5):816-36.e4. [doi: 10.1016/j.spinee.2013.09.036] [Medline: 24412032]

89. Waddell G, Newton M, Henderson I, Somerville D, Main CJ. A Fear-Avoidance Beliefs Questionnaire (FABQ) and the role of fear-avoidance beliefs in chronic low back pain and disability. Pain 1993 Feb;52(2):157-168. [Medline: $\underline{8455963]}$

90. Chaory K, Fayad F, Rannou F, Lefèvre-Colau MM, Fermanian J, Revel M, et al. Validation of the French version of the fear avoidance belief questionnaire. Spine (Phila Pa 1976) 2004 Apr 15;29(8):908-913. [Medline: 15082995]

91. Armstrong T, Bull F. Development of the World Health Organization Global Physical Activity Questionnaire (GPAQ). J Public Health 2006 Mar 2;14(2):66-70. [doi: 10.1007/s10389-006-0024-x]

92. Schaller A, Dejonghe L, Haastert B, Froboese I. Physical activity and health-related quality of life in chronic low back pain patients: a cross-sectional study. BMC Musculoskelet Disord 2015 Mar 19;16:62 [FREE Full text] [doi: 10.1186/s12891-015-0527-0] [Medline: 25887138]

93. Dworkin RH, Turk DC, Farrar JT, Haythornthwaite JA, Jensen MP, Katz NP, IMMPACT. Core outcome measures for chronic pain clinical trials: IMMPACT recommendations. Pain 2005 Jan;113(1-2):9-19. [doi: 10.1016/j.pain.2004.09.012] [Medline: 15621359]

94. Mazaheri M, Heidari E, Mostamand J, Negahban H, van Dieen JH. Competing effects of pain and fear of pain on postural control in low back pain? Spine (Phila Pa 1976) 2014 Dec 01;39(25):E1518-E1523. [doi: 10.1097/BRS.0000000000000605] [Medline: 25271501]

95. Caffaro RR, França FJ, Burke TN, Magalhães MO, Ramos LA, Marques AP. Postural control in individuals with and without non-specific chronic low back pain: a preliminary case-control study. Eur Spine J 2014 Apr;23(4):807-813 [FREE Full text] [doi: 10.1007/s00586-014-3243-9] [Medline: 24570125]

96. Kahraman T, Ozcan Kahraman KB, Salik Sengul Y, Kalemci O. Assessment of sit-to-stand movement in nonspecific low back pain: a comparison study for psychometric properties of field-based and laboratory-based methods. Int J Rehabil Res 2016 Jun;39(2):165-170. [doi: 10.1097/MRR.0000000000000164] [Medline: 27031182]

97. Hermens HJ, Freriks B, Disselhorst-Klug C, Rau G. Development of recommendations for SEMG sensors and sensor placement procedures. J Electromyogr Kinesiol 2000 Oct;10(5):361-374. [Medline: 11018445]

98. Lewek MD, Rudolph KS, Snyder-Mackler L. Control of frontal plane knee laxity during gait in patients with medial compartment knee osteoarthritis. Osteoarthritis Cartilage 2004 Sep;12(9):745-751 [FREE Full text] [doi: 10.1016/j.joca.2004.05.005] [Medline: 15325641] 
99. Konrad P. Noraxon. 2006. The ABC of EMG: A Practical Introduction to Kinesiological Electromyography URL: https:/ /www.noraxon.com/wp-content/uploads/2014/12/ABC-EMG-ISBN.pdf [accessed 2018-03-22] [WebCite Cache ID 6y6ssnENy]

100. Mohseni Bandpei MA, Rahmani N, Majdoleslam B, Abdollahi I, Ali SS, Ahmad A. Reliability of surface electromyography in the assessment of paraspinal muscle fatigue: an updated systematic review. J Manipulative Physiol Ther 2014 Sep;37(7):510-521. [doi: 10.1016/j.jmpt.2014.05.006] [Medline: 25204717]

101. Davis RB, Õunpuu S, Tyburski D, Gage JR. A gait analysis data collection and reduction technique. Hum Mov Sci 1991 Oct;10(5):575-587 [FREE Full text] [doi: 10.1016/0167-9457(91)90046-Z]

102. Schmid S, Studer D, Hasler CC, Romkes J, Taylor W, Brunner R, et al. Using skin markers for spinal curvature quantification in main thoracic adolescent idiopathic scoliosis: an explorative radiographic study. PLoS One 2015;10(8):e0135689 [FREE Full text] [doi: 10.1371/journal.pone.0135689] [Medline: 26270557]

103. Mahallati S, Rouhani H, Preuss R, Masani K, Popovic MR. Multisegment kinematics of the spinal column: soft tissue artifacts assessment. J Biomech Eng 2016 Jul 01;138(7). [doi: 10.1115/1.4033545] [Medline: 27151927]

104. Esola MA, McClure PW, Fitzgerald GK, Siegler S. Analysis of lumbar spine and hip motion during forward bending in subjects with and without a history of low back pain. Spine (Phila Pa 1976) 1996 Jan 1;21(1):71-78. [Medline: 9122766]

105. Henchoz Y, Tétreau C, Abboud J, Piché M, Descarreaux M. Effects of noxious stimulation and pain expectations on neuromuscular control of the spine in patients with chronic low back pain. Spine J 2013 Oct;13(10):1263-1272. [doi: 10.1016/j.spinee.2013.07.452] [Medline: 24090825]

106. Lamoth CJ, Daffertshofer A, Meijer OG, Beek PJ. How do persons with chronic low back pain speed up and slow down? Trunk-pelvis coordination and lumbar erector spinae activity during gait. Gait Posture 2006 Feb;23(2):230-239. [doi: 10.1016/j.gaitpost.2005.02.006] [Medline: 16399520]

107. Van Daele U, Hagman F, Truijen S, Vorlat P, Van Gheluwe B, Vaes P. Decrease in postural sway and trunk stiffness during cognitive dual-task in nonspecific chronic low back pain patients, performance compared to healthy control subjects. Spine (Phila Pa 1976) 2010 Mar 01;35(5):583-589. [doi: 10.1097/BRS.0b013e3181b4fe4d] [Medline: 20147880]

108. Ruhe A, Fejer R, Walker B. Center of pressure excursion as a measure of balance performance in patients with non-specific low back pain compared to healthy controls: a systematic review of the literature. Eur Spine J 2011 Mar;20(3):358-368 [FREE Full text] [doi: 10.1007/s00586-010-1543-2] [Medline: 20721676]

109. Ruhe A, Fejer R, Walker B. Is there a relationship between pain intensity and postural sway in patients with non-specific low back pain? BMC Musculoskelet Disord 2011 Jul 15;12:162 [FREE Full text] [doi: 10.1186/1471-2474-12-162] [Medline: 21762484]

110. Barre A, Armand S. Biomechanical ToolKit: open-source framework to visualize and process biomechanical data. Comput Methods Programs Biomed 2014 Apr;114(1):80-87 [FREE Full text] [doi: 10.1016/j.cmpb.2014.01.012] [Medline: 24548899]

\author{
Abbreviations \\ 5CSTS: 5 consecutive sit-to-stand \\ CCI: cocontraction index \\ FABQ: fear-avoidance belief questionnaire \\ GPAQ: global physical activity questionnaire \\ HADS: Hospital Anxiety and Depression Scale \\ HUG: Geneva University Hospital \\ ICF: International Classification of Functioning, Disability, and Health \\ LBP: low back pain \\ ODI: Oswestry Disability Index \\ PA: physical activity \\ PCS: pain catastrophizing scale \\ STS: sit-to-stand \\ sEMG: surface electromyography \\ TCC: time of cocontraction
}


Edited by G Eysenbach; submitted 20.10.17; peer-reviewed by M Alshehri, M Puttaroo; comments to author 08.11.17; accepted 22.11.17; published 23.04.18

Please cite as:

Rose-Dulcina K, Vuillerme N, Tabard-Fougère A, Dayer R, Dominguez DE, Armand S, Genevay S

Identifying Subgroups of Patients With Chronic Nonspecific Low Back Pain Based on a Multifactorial Approach: Protocol For a Prospective Study

JMIR Res Protoc 2018;7(4):e104

URL: http://www.researchprotocols.org/2018/4/e104/

doi: $10.2196 /$ resprot.9224

PMID: 29685875

CKevin Rose-Dulcina, Nicolas Vuillerme, Anne Tabard-Fougère, Romain Dayer, Dennis E Dominguez, Stephane Armand, Stéphane Genevay. Originally published in JMIR Research Protocols (http://www.researchprotocols.org), 23.04.2018. This is an open-access article distributed under the terms of the Creative Commons Attribution License (https://creativecommons.org/licenses/by/4.0/), which permits unrestricted use, distribution, and reproduction in any medium, provided the original work, first published in JMIR Research Protocols, is properly cited. The complete bibliographic information, a link to the original publication on http://www.researchprotocols.org, as well as this copyright and license information must be included. 